\title{
Understanding the Reasons for Malaysian Youth Participation in Volunteering Activities
}

\author{
By Siti Raba'ah Hamzah* \\ Turiman Suandi ${ }^{*}$ \\ Jasmin Arif Shah ${ }^{*}$ \\ Ismi Arif Ismail ${ }^{+}$ \\ Azimi Hamzah
}

This paper explores the reasons for Malaysian youth participating in volunteering activities and examines the variables that predict their participation. The subjects used in the study were from the Department of Youth and Sports, Malaysia. A total of 251 respondents, between the ages 15 to 25 ( $M$ age $=20.2, S D=2.7)$, participated in this study. Using the Social Exchange theory as a framework for this study, three main factors contributing to youth participation in volunteering activities were the perceived benefits from volunteering ("benefits"), the personal needs or fulfillment of the respondents to volunteer ("needs"), and their personal reasons for volunteering ("reasons"). Our findings showed that the "benefits" included learning to shoulder responsibility, broadening interest, fostering relationships, building teamwork spirit, and encouraging socialisation within the community setting. The "need" to volunteer was associated with the desire to unleash leadership potential and improve communication skills. Finally, the "reasons" for volunteering included using leisure time meaningfully, getting new experience, improving confidence and self-esteem, attaining emotional stability, and getting a better understanding of the realities of life. The findings indicated positive relationships between the participation and "benefits", "needs" and "reasons" to volunteer. However, "reason" was the strongest predictor of the youth becoming volunteers.

Keywords: Participation, Volunteer Activities, Youth.

\footnotetext{
${ }^{*}$ Youth and Sport Officer, Department of Professional Development and Continuing Education, University Putra Malaysia, Malaysia.

${ }^{\dagger}$ Lecturer, Institute for Social Science Studies, Putra Malaysia University, Malaysia.

${ }^{\star}$ Lecturer, Department of Professional Development and Continuing Education, Putra Malaysia University, Malaysia.

${ }^{+}$Reseacher, Department of Professional Development and Continuing Education, Putra Malaysia University, Malaysia.

Department of Professional Development and Continuing Education, Universiti Putra Malaysia, Malaysia.
} 


\section{Introduction}

The spirit of volunteerism among Malaysians first swept the country in the $19^{\text {th }}$ century. Initially fuelled by religious and community revivals in the 1950 s, the first generation of volunteers were drawn to charity in a very personal and religious manner (Hussain 1986). However, increasingly throughout the twentieth century, those who became wealthy withdrew from direct community involvement. Today's volunteer efforts are a reflection of this historical development and diversified growth of the Malaysian volunteer force in many ways. A trend pointing towards this continuous growth of volunteer demand is that many voluntary, public, and private human service agencies are recruiting volunteers to complement and enrich service delivery (Cnaan and GoldbergGlen 1991).

In Malaysia, one such effort is the creation of a new organization called Mycorps (Ministry of Youth and Sports 2010), a joint effort between the Ministry of Youth and Sport and relevant agencies such as Youth Council Malaysia (MBM), Malaysian Relief Agency, Yayasan Salam, Youth Council Mosques and other voluntary bodies within and outside the country. MyCorps aims to promote and enhance the spirit of volunteerism among youth through their involvement at local and international levels, as well as to create awareness in youth about issues related to domestic and international peace, war, conflict, cohesion, education, disaster, health and so on. It is a national institutionalized youth platform on which youth can engage and participate in community welfare and humanitarian activities.

Encouraging youth to volunteer to serve the community and individual is widely viewed as beneficial to the society. Throughout history, volunteering is a contribution to the society in one form or another without monetary reimbursement. Although there is no financial return for volunteering, research has shown that volunteers do expect other considerations for the work that they do. Studies show that most youths participate actively in volunteering activities to satisfy their own needs while helping others in their community (Gage and Thapa 2012). Up to date, most of the studies on volunteering in Malaysia include examining the factors that influence people to volunteer (Turiman et al. 2011), the challenges in voluntary work (Kauthar et al. 2013), empowering youth volunteerism and motivating factors (Mardiyyah et al. 2013), altruism as motivational factors toward volunteerism among youth (Zaleha and Mohd Ramlan 2012) and psychosocial factors that influence the volunteers to offer their services to the community (Surjit et al. 2005). In the light of the growing interest among youths to engage in work-related volunteering activities and an increase in the kinds of the programmes offered, studies on the understanding of youth participation are necessary. The current study focuses on youth participation and the reasons why they get involved in volunteering programs and activities in Malaysia. 


\section{The Current Study}

Research related to understanding youth participation in volunteering activities in Malaysia is still lacking. Hence this study has been undertaken to examine the "benefits", "needs" and "reasons" that influence Malaysian youth involvement in volunteerism.

Flanagan and Levine (2010) evaluate the effect of youth participation on their personal and social development, such as skills and knowledge, academic achievement and school performance, sense of direction, social connectedness, and their psychosocial well-being. Other studies evaluate youth participation to vis-a-vis organizational development, which is related to administrative structure and allocation of the resources, leadership, management and collaboration with other organization (Evans and Prilleltensky 2007). However, according to Morrissey (2000), it is difficult to document such changes in personal, social and organizational development with regard to youth participation in volunteering activities.

Realizing young people's right to participate voluntarily in community projects is vital to ensure the achievement of internationally agreed developmental goals, such as those by the International Conference on the Population Development (ICPD) and the Programme of Action and the Millennium Development Goals (MDGs). The youth must be empowered to contribute to informed decisions about their personal, family, social, economic, environmental and political development. Youth participation is a right protected by the Convention on the Rights Child (United Nations General Assembly 2011), which states that children have the right to participate in the decision-making processes related to their lives, including participation in volunteering activities.

There should be greater effort to create a supportive environment for participation, engagement and volunteering for young people, including what can be achieved through youth-led organizations, to volunteer within their communities, to allow them to contribute to their own livelihoods, and improve their capability, and employability. The volunteers can thus be molded into active leaders and useful citizens. Studies show that young people engaged in volunteering also develop positive social behaviours that can help reduce negative risk-taking. Volunteering can also help young people prepare for employment and their transition to responsible adulthood.

\section{Literature Review}

The existing literature on participation in various program and activities among young people often views them as a homogenous group, having the same experiences and interactions with decision-makers in their communities and with the government. Realistically, this group of young people is a heterogeneous group consisting of different cultures and subcultures, their experience differs throughout their life depending as where they live and with 
whom they interact. Different levels or models of youth participation have been identified (Hart 1992) but they have a common end point that focuses on the partnership and share of power between other powerful organisational forms such as the community where they live. This is noted by Shier (2001) who defines participation as a continuum along five categories of young people: listened to; supported to express views; views are taken into account; involved in decision-making; share power and responsibility for decision-making.

Additionally, participation tends to be conceptualised in three main approaches. First, both individualised and institutionalised acts that people do by themselves are aimed at trying to influence the political outcomes; second, a group or collectively based action that is usually undertaken on a voluntary basis which can influence the opinion of the government or general public; and third, fostered by governments and other formal organisations to include people and groups overtly within their decision-making processes. These three approaches of understanding participation are often used interchangeably in the literature by academics, policy makers and practitioners, which included the fact that they are significantly different approaches of young people to become involved in politics and society. Different approaches to understand participation are more or less prescriptive in both recognising how young people are currently involved in government and community decision-making, and in making recommendations on how they ought to be involved in the future.

Driskell (2002) developed a dimension of youth participation based on two strong concepts: first, the power of young people to make decisions and effect changes and second the interaction of young people with others in their community. Merging these two concepts sheds new light on the continuous debate around the ultimate goal of voluntary participation in community services by young people. Focusing on volunteers working with the communities Driskell and Neema (2009) developed a framework that presents participation as a spatial practice shaped by five dimensions, viz.: normative, structural, operational, physical, and attitudinal. All these dimensions are mutually constitutive and highly interactive for volunteers.

To summarize, participation can be viewed as a collective action involving activities undertaken together with others, in a formal or informal group structure, to achieve a shared goal, often for the creation of social and political change. Such participation is through activities like joining local community or volunteering groups.

\section{The Benefits of Participation in Volunteering Activities}

Volunteers are individuals who allot a part of their time to help community members without being materially rewarded; they assume responsibility for voluntary activity, seeking personal satisfaction and acquisition of new experience (Adler 2011). According to Wilson (2000) the decision to volunteer is based on a rational weighing of its costs and benefits. 
Volunteer motivation is one of the main issues in volunteerism that can be conceptualised within the framework of the Social Exchange theory, i.e. in order for volunteer efforts to be sustained over time, rewards to volunteers must exceed, or at minimum, balance out the costs (Schafer 1979). The theory suggests that people contribute to the degree that they perceive that they are being rewarded. When they perceive imbalance between contributions and rewards, an individual is likely to move toward a greater equilibrium. An individual who perceives that rewards for volunteering are imbalanced with contributions is likely to discontinue involvement. According to Blau (1964), the Social Exchange theory describes six types of social rewards, viz.: personal attraction, social acceptance, social approval, instrumental services, respect/prestige, and compliance/power. With regard to volunteering, rewards can take the form of learning, love, gratitude, perceived higher status associated with giving back to the community, and an overall sense of positive spirituality.

Literature shows that, there are multiple benefits from volunteering. Research has shown that volunteering can enhance personal skill development, sense of civic responsibility, career choice and employability (Hall et al. 2009, Musick and Wilson 2008). According to Holdsworth (2010), volunteers have altruistic and instrumental reasons for helping out in their community. Often, volunteers learn new skills and gain experience that may benefit their career advancement. Studies have also identified volunteering programme characteristics that maximize benefits, especially to young volunteers. These include activities that provide opportunities for 1 . youth autonomy and decision-making, 2. collaborative work with youth and adults, 3. reflection, 4. psychological engagement, and 5. building competence, confidence, character, connection and caring attitude (Stukas et al. 1999).

\section{Need to Volunteer}

According to the Social Exchange theory, the need to volunteer is motivated by self-interest. It assumes that self-interest has no genetic basis. The theory hypothesizes that social exchanges comprise actions conditional on the rewarding actions of others i.e. it can increase the probability that someone will help us in return in the future; it can relieve the personal distress of the bystander; and it can help us gain social approval and increased self-worth.

Another important point to note is that volunteering can provide to the social capital (Wollbaeck and Selle 2002) and human capital (McNamara and Gonzales 2011, Schram and Dunsing 1981). Social capital, as defined by Bourdieu (1985), is "the aggregate of the actual or potential resources which are linked to possession of a durable network of more or less institutionalized relationships of mutual acquaintance or recognition". According to Putnam (1993: 167), social capital is often defined as "those features of social organization, such as trust, norms and networks that can improve the efficiency of society by facilitating coordinated actions". Volunteering activities can 
expand the circle of professional contacts, durable networks, employment leads and social relationships. Statham and Rhoton (1986) suggest that volunteering enhances human capital, which includes knowledge, skills, abilities, leadership opportunities and work experience. Based on the literature, volunteering can serve as a pathway to employment through increases in one's social capital and human capital. The combination of these two important aspects will enhance the volunteers' skills and experience. When volunteers gain or update skills that are needed in the workplace through their volunteer activities, they will become more employable or productive at their workplace.

Research findings consistently show strong correlations between social capital and the tendency to volunteer (Wilson 2000). Volunteerism is usually encouraging social contacts through either a direct request or by setting an example. People are more likely to volunteer in response to a personal appeal, particularly from a current volunteer. It was found that people who were asked by an active volunteer to offer their services were four times more likely to do so than if they were asked by others (Penner 2004). In fact, social capital can also explain the impact of human capital (income and education) on volunteering, given that individuals with higher positions at work and those who have attended college have more social contacts. Furthermore, social networks provide rewards for helping behaviours, in the form of increasing positive attitudes from significant others and increased prestige.

\section{Reasons to Get Involved in Volunteering Activities}

Many studies have investigated why people volunteer and what benefits volunteers gain from helping others. Cross-culturally, studies have shown that people in different countries have different perceptions of volunteering, varying with local cultures, political climate, government policy and history. This is due to the fact that helping others has been found to be an important and consistent factor amongst volunteers of all ages (Brudney 1994, Nichols and King 1999). Research on volunteering also has examined and categorized the motivational objectives of individuals who donate their services in volunteering programmes. One of the major motives for volunteering is giving something worthwhile back to society. In this regard, Yeung (2004) identifies different motivations such as altruism, social contact, personal interest and emotional needs as some of the reasons for people's involvement in volunteering activities. Some motives, especially those associated with youth volunteering include, sharpening or stretching one's job skills, testing new careers, building a resume and achievement, affiliation or power.

In Malaysia, a number of studies have contributed to the understanding of the volunteerism movement. Previous empirical studies have focused on altruism as a motivational factor contributing to volunteerism among youth (Zaliha and Mohd Ramlan 2012). Other studies include investigations on volunteerism and the development of the Malaysian social care system (Hawa 2002), empowerment of youth volunteerism and global motivating factors 
(Mardhiyyah et al. 2013), and factors contributing toward sustainability of youth organizations as partners in community development (Azimi and Turiman 2002).

\section{Methods}

\section{Participants and Procedures}

The participants in this study were drawn from the Department of Youth and Sports, Malaysia, which had over 2000 volunteers belonging to 40 youth organizations. Many committee members of the organization were volunteers who actively took part in volunteering programmes. Using a random sampling technique to ensure the representativeness of the chosen sample, a total of 251 respondents participated in this study. There were $123(49.0 \%)$ males and 128 $(51.0 \%)$ females; 148 respondents $148(59.0 \%)$ were from suburban and rural areas, and $103(41.0 \%)$ from urban areas. The mean age of the participants was 20.2 years $(S D=2.7)$, with a range of 15 to 25 years.

\section{Measures}

This study was aimed at identifying the reasons for Malaysian youth participation in volunteering activities. Items were rated based on a 10-point Likert-scale format, ranging from 1 (strongly disagree) to 10 (strongly agree).

- Statements about the benefits of youth participation in volunteering activities were given to elicit responses from the respondents: "Volunteering activities polish my leadership skills"; "Volunteering activities mould good values in me"; "Volunteering activities provide the opportunity to increase social capital"; "Volunteering activities improve social interaction"; "Volunteering activities help problem-solving"; "Volunteering activities boost self-confidence"; "Volunteering activities create happiness"; "Volunteering activities enhance sense of belonging".

- In addition to statements on participation in volunteering, we also included a number of measures to assess the benefits of youth volunteering in social capital. We asked respondents to identify, from a given list, the main pillars for social capital (leadership, entrepreneurship, team-work, communication, good ethics and moral, life-long learning, critical thinking).

- Next, the respondents were requested to identify their reasons for participating in volunteering activities. The questionnaire was framed as follows: "Involvement in volunteering activities helps improve employability"; "Participating in volunteering activities helps me make new friends"; "Getting involved in volunteering activities helps to develop new contacts"; "Participating involved in volunteering activities enriched positive lifestyle choices and behavior"; "Involvement in volunteering activities makes me feel 
Vol. 3, No. $1 \quad$ Hamzah et al.: Understanding the Reasons for Malaysian Youth...

appreciated"; "Involvement in volunteering activities helps me fulfill a religious requirement"; "Participation in volunteering activities help support corporate social responsibility"; "Participation in volunteering activities enables me to support the government development policies" "Involvement in volunteering activities can create social networks of trust and cooperation".

Finally, the questionnaire investigated why youth felt the need to get involved in volunteering activities. The participants were required to respond to these statements: "I feel I am doing the right thing"; "I need to have a sense of accomplishment"; "I feel I can play a role in community development", "I need to fulfill a spiritual obligation"; "I need help with my personal growth"; "I need to encourage sharing among communities"; "I need to make life better for the coming generations"; "It helps me to deal better with my day to day problems"; "It gives me a sense of having accomplished something useful in my community"; and "It makes me act in a responsible manner towards the development of the country".

\section{Results}

Bivariate Correlation (Pearson's $r$ )

The relationships between participation and benefit, need and reason were analysed using the Pearson product-moment correlation coefficients. Preliminary analyses were performed to ensure that there were no violations of the assumptions of normality and linearity. As depicted in Table 1, according to Cohen (1988), the strongest linear relationship was found to exist between participation and reasons to volunteer $(r=0.816, p=0.0001)$. The positive correlation coefficient of 0.816 indicates the score for participation and also the rating of reason to participate in volunteering activities. This means that the stronger the reason to volunteer, the higher the participation in volunteering activities will be. For example, the respondent's mention the reason why they participate in volunteering activities because of its helps to improve employability, make new friends, develop new contact and support corporate social responsibility.

The second highest relationship was found between participation and benefit for volunteers $(r=0.702, p=0.0001)$ and the correlation coefficient indicates that there was a strong positive linear relationship between participation and benefit for volunteers. The result shows that the higher the perceived benefit of volunteering, the higher the participations. The benefit to participate in volunteering activities reported by the respondent's included polishing their leadership skill, mould good values, increasing the social capital, improve social interaction and enhance sense of belonging.

Finally, the relationship was between participation and the need to volunteer $(r=0.689, p=0.003)$ and a value of 0.689 indicates a positive linear relationship. Exemplars of the need to participate to volunteering activities 
among the respondent's included volunteering is the right thing to do, as a role in community development, as a spiritual obligation, helping the personal growth, sharing among communities and acting in a possible manner to help the development of the country.

Table 1. Means, Standard Deviations and Bivariate Correlations Among Predictor and Dependent Variables for Volunteering

\begin{tabular}{|c|c|c|c|c|c|}
\hline Variable & M & SD & Participation & Benefit & Needs \\
\hline Participation & 7.212 & 1.405 & 1.000 & & \\
\hline Benefit & 7.670 & 1.535 & $0.702^{* *}$ & & \\
\hline Needs & 7.599 & 1.625 & $0.689^{* *}$ & $0.609^{* *}$ & \\
\hline Reason & 7.217 & 1.355 & $0.816^{* *}$ & $0.521^{* *}$ & 0.685 \\
\hline
\end{tabular}

** Significant at $p<0.001$ level.

\section{Regression Analysis on Predictors of Participation to Volunteers}

The data were further analysed using a utilized multiple regression analysis (Table 2) to identify the factors which influence participation in volunteering activities. These factors included "benefit", "need" and "reason". To determine the extent that the research data fits the proposed multiple linear regression model, the enter regression method was used. The ANOVA table reveals that the F-statistics $(F=168.897)$ was large and the corresponding $p$ value was highly significant (0.0001) or lower than the alpha value of 0.05 . This indicates that the model as a whole is significant $F(3,250)=168.897, p=$ 0.0001 . However, based on the enter method used; it is relevant to note that the $\mathrm{R}$ square value of the one correlation coefficient between participation and "reason" is $0.816^{2}=0.67$. It does not require a combination of three predictor variables to reach a value of 0.67 . Not surprisingly, Table 2 shows that the other two variables, "need" $(p=0.101)$ and "benefit" $(p=0.554)$ do not contribute significantly to the amount of variance that is explained.

As depicted in Table 2, the largest beta coefficient is 0.695, which is for the reason to participate and this corresponds with the highest t-statistic of 10.156. This means that the reason to participate variable makes the strongest unique contribution to explaining the dependent variables of engagement in volunteering activities, when the variance explained by all other predictor variables in the model is held constant. It suggests that one standard deviation increase in reason to participate is associated with 0.695 standard deviation increase in engagement towards volunteer activities. The Beta value for needs is $(0.109)$, followed by the benefit to volunteer, which is the lowest $(0.043)$. The result showed that the higher the reason to participate, the greater the possibility of participation in volunteering activities. 
Table 2. Predictors of Volunteer Participation in Volunteering Activity

\begin{tabular}{|c|c|c|c|c|c|}
\hline Factors & $\begin{array}{c}\text { Beta } \\
\text { (Unstandardized } \\
\text { Coefficients) }\end{array}$ & $\begin{array}{c}\text { Std } \\
\text { error }\end{array}$ & $\begin{array}{c}\text { Beta } \\
\text { (Standardized } \\
\text { Coefficients) }\end{array}$ & $\boldsymbol{t}$ & Sig. \\
\hline Constant & 0.993 & 0.283 & & 3.503 & 0.000 \\
\hline Benefit & 0.039 & 0.066 & 0.043 & 0.953 & 0.554 \\
\hline Needs & 0.095 & 0.057 & 0.109 & 1.648 & 0.101 \\
\hline Reason & 0.721 & 0.071 & 0.695 & 10.156 & 0.000 \\
\hline
\end{tabular}

$\mathrm{R}=0.820, \mathrm{R}^{2}=0.672, \mathrm{~F}=168.897, p=0.000$.

\section{Conclusions and Recommendations}

Understanding why Malaysian youth participate in volunteering activities is important to the development of social and human capital in the country. In this study, three factors were explored, viz.: "benefit", "need" and "reason" to get involved. In the first set of analyses, we tested the relationship between "participation" and "benefit", "need" and "reason" to volunteer. In the second set of analyses, we examined the data using a multiple regression analysis to identify which factors influence participation in volunteering activities.

The results of the study are consistent with the view that the reason to volunteer was the strongest predictor of youth becoming a volunteer. As previously mentioned, many volunteer motivation studies have the view that beyond the facilities and promotion from the volunteer organization to attract the volunteers, a set of psychological needs such as personal interest and selfactualizations were very important. That is, that through a volunteering experience, an individual might accomplish their reason to participate in volunteering activities. This study also shows volunteering activities that help youth boost their employability, forge new friendships, develop new contacts, create social networks of trust and cooperation, receive more appreciation, fulfill religious requirements, support corporate social responsibility and contribute to government development policies.

Another contribution of the study is revelation that the benefit for volunteering was positively related to participation. Volunteering was perceived to have enabled volunteers to develop skills which might be useful in their future career or help =obtain employment, gain academic credits or even aid career advancement. The findings showed that volunteering activities also helped in unleashing leadership skills; molding good values; providing opportunities to increase social capital; enlarging the social circle; help problem-solving; boosting self-confidence; increasing happiness and enhancing sense of belonging.

Finally, these findings make some contribution to the social exchange theory about the need to volunteer that is motivated by self interest which is related to social capital and human capital. The need to volunteer included the desire to accomplish the following: do the right thing; fulfill a sense of accomplishment; play a role in community development; restore or contribute to spirituality; enhance personal growth; encourage sharing among 
communities; make life better for the coming generations; help to deal with day to day problems; accomplish something useful in the community; and act in a responsible manner for the development of the country.

These findings suggest that benefits, needs and reasons to volunteer are important factors which influence an individual's decision to participate in volunteering activities. This information would benefit volunteer organizations because they could use this data to tailor their promotions to invite more volunteers to participate in volunteering projects. They would also be informed of which kind of benefits, needs and reasons to focus on in order to expand the number of potential volunteers.

Using the Social Exchange theory, this study provides a platform for appreciating youth participation in the voluntary activities and to continually reassess and balance the rewards and costs of their involvement. Positive relationships between participation and benefits, need and reason to volunteers all appear to contribute to greater satisfaction and intention to remain committed to volunteering activities in a longer term.

Nevertheless, it would be beneficial to conduct in-depth interviews to discover more details about what motivate youths to volunteer in the volunteering activities. Perhaps the sample for future studies could include youth who are not from the Department of Youth and Sports. Students and young working adults should be interviewed to obtain a more comprehensive understanding of their views regarding youth participation in volunteering activities. It is important to ensure that today young volunteers are groomed to become active leaders and useful citizens. Hence more research to shed light in this area would be very useful.

\section{References}

Adler R (2011) The Volunteer Factor. Journal of Personality and Social Psychology 62(2): 124-138.

Azimi H, Turiman S, Ezhar T (2002) Youth Organization in Malaysia: Development and Potential Enhancement. Serdang: Universiti Putra Malaysia.

Bourdieu P (1985) The forms of capital. In Richardson JG (ed) Handbook of Theory and Research for the Sociology of Education. New York: Greenwood, 241-258.

Blau PM (1964) Exchange and Power in Social Life. New York: Wiley.

Brudney JL (1994) Designing and managing volunteer programs. In Renz DO (ed) The Jossey-Bass Handbook of Nonprofit Leadership and Management, $3^{\text {rd }}$ edn. San Francisco: Jossey-Bass Inc., 310-344.

Cohen J (1988) Statistical Power Analysis for the Behavioral Sciences, $2^{\text {nd }}$ edn. Hillsdale, NJ: Erlbaum.

Cnaan RA, Goldberg-Glen RS (1991) Measuring motivation to volunteer in human services. Journal of Applied Behavioral Sciences 27(3): 269-283.

Driskell D (2002) Creating Better Cities with Children and Youth: A Manual for Participation. London: UNESCO and Earthscan Publications.

Driskell D, Neema K (2009) Creating space for participation: the role of organizational practice in structuring youth participation. Community Development 40(4): 367-380. 
Evans SD, Prilleltensky I (2007) Youth and democracy: participation for personal, relational and collective well-being. Journal of Community Psychology 35(6): 681-692.

Flanagan C, Levine P (2010) Civic engagement and the transition to adulthood. The Future of Children 20(1): 159-80.

Gage III RL, Thapa B (2012) Volunteer motivations and constraints among college students: analysis of the volunteer function inventory and leisure constraints models. Nonprofit and Voluntary Sector Quarterly 41(3): 405-430.

Hall M, Lasby D, Ayer S, Gibbons W (2009) Caring Canadians, Involved Canadians: Highlights from the 2007 Canada Survey of Giving, Volunteering and Participating. Ottawa, ON: Statistics Canada.

Hart R (1992) Children's participation: from tokenism to citizenship. UNICEF Innocenti Essays 4. Florence, Italy: UNICEF/International Child Development Center.

Hawa SA (2002) Volunteerism and the Development of Malaysian Social Care System. Pulau Pinang: School of Health Science, Universiti Sains Malaysia.

Holdsworth C (2010) Student Volunteers: A National Profile. London: Volunteering England/Institute of Volunteering Research.

Hussain M (1986) Gerakan Belia di Malaysia [Youth Movement in Malaysia]. Shah Alam, Selangor: Gateway Publishing House Bhd.

Kamaludin KM, Muhammad M, Wahat NW, Ibrahim R (2013) Challenges in volunteering from cancer care volunteers perspectives. Asian Pacific Journal of Cancer Prevention 14(8): 4795-4800.

Sahri M, Murad K, Alias A, Sirajuddin MDM (2013) Empowering youth volunteerism: the importance and global motivating factors. Journal of Educational and Social Research 3(7): 502-507.

Mcnamara TK, Gonzales E (2011) Volunteer transitions among older adults: the role of human, social, and cultural capital in later life. Journal of Gerontology Series B - Psychological Sciences and Social Sciences 66(4): 490-501.

Ministry of Youth and Sports, Mycorps (2010) Concept Paper on Implementation Initiative "Mycorps" Laboratory of Transformation of Youth Initiative. [Online] Retrieved from http://bit.ly/1SL3EHY. [Accessed 14 April 2014].

Morrissey J (2000) Indicators of citizen participation: Lessons from learning teams in rural EZ/EC communities. Community Development Journal 35(1): 59-74.

Musick MA, Wilson J (2008) Volunteers: A Social Profile. Bloomington: Indiana University Press.

Nichols G, King L (1999) Redefining the recruitment niche for the Guide Association in the UK. Leisure Sciences 21(4): 307-320.

Penne RLA (2004) Volunteerism and social problems: Making things better or worse?. Journal of Social Issues 60(3): 645-666.

Putnam RD (1993) Making Democracy Work: Civic Traditionsin Modern Italy. Princeton, NJ: Princeton University Press.

Schafer RB (1979) Equity in a relationship between individuals and a fraternal organization. Nonprofit and Voluntary Quarterly 8: 12-20.

Schram V, Dunsing M (1981) Influences on married women's volunteer work participation. Journal of Consumer Research 7: 371-379.

Shier H (2001) Pathways to participation: Openings, opportunities and obligations. Children and Society 15(2): 107-117.

Statham A, Rhoton P (1986) Mature and Young Women's Volunteer Work, 19741981. Columbus: Center for Human Resource Research, The Ohio State University. 
Stukas AA, Clary GE, Snyder M (1999) Service learning: who benefits and why. Social Policy Report: Society for Research in Child Development 13: 1-20.

Surjit SG, Rahim MS, Bahaman AS, Raja Ahmad Tajudin Shah, Lumayag LA (2005) To volunteer or not to volunteer: the case of Malaysian public service retirees. Pertanika Journal of Social Sciences and Humanities 13(2): 199-209.

Turiman S, Siti Raba'ah Hamzah, Wan Mahzom Ahmad Shah, Mohd Rezal Hamzah, Azizan Bahari, Ismail Ali, Wan Ibrahim Wan Ismail and Mohd Hafizi Ismail (2011) Determinants of Student Volunteering in Malaysian Public Universities. International Conference on Youth Development, Palm Garden, Putrajaya. $1^{\text {st }}-3^{\text {nd }}$ November 2011.

United Nations General Assembly (2011) A Resource Guide on the UN Committee on the Rights of the Child General Comment. Retrieved from http://uni.cf/1lq6017. [Accessed 14 April 2014].

Wilson J (2000) Volunteering. Annual Review of Sociology 26: 215-240.

Wollbaeck D, Selle P (2002) Does participation in voluntary associations contribute to social capital? the impact of intensity, scope, and type. Nonprofit and Voluntary Sector Quarterly 31: 32-61.

Yeung AB (2004) The octagon model of volunteer motivation: results of a phenomenological analysis. Voluntas: International Journal of Voluntary and Nonprofit Organizations 15(1): 21-46.

Zaliha H, Arshad MRM (2012) Altruism as motivational factors toward volunteerism among youth in Petaling Jaya. International Proceedings of Economics Development and Research 54: 225. Retrieved from doi:10.7763/IPEDR. [Accessed 15 May 2014]. 
